\title{
Long-term changes in visual outcomes and ocular morphometrics after myopic and toric phakic intraocular lens implantation
}

Citation for published version (APA):

Jonker, S. M. R., Berendschot, T. T. J. M., Ronden, A. E., Saelens, I. E. Y., Bauer, N. J. C., \& Nuijts, R. M. M. A. (2019). Long-term changes in visual outcomes and ocular morphometrics after myopic and toric phakic intraocular lens implantation: Five- and 10-year results. Journal of Cataract and Refractive Surgery, 45(10), 1470-1479. https://doi.org/10.1016/j.jcrs.2019.05.044

Document status and date:

Published: 01/10/2019

DOI:

10.1016/j.jcrs.2019.05.044

Document Version:

Publisher's PDF, also known as Version of record

\section{Document license:}

Taverne

Please check the document version of this publication:

- A submitted manuscript is the version of the article upon submission and before peer-review. There can be important differences between the submitted version and the official published version of record.

People interested in the research are advised to contact the author for the final version of the publication, or visit the DOI to the publisher's website.

- The final author version and the galley proof are versions of the publication after peer review.

- The final published version features the final layout of the paper including the volume, issue and page numbers.

Link to publication

\footnotetext{
General rights rights.

- You may freely distribute the URL identifying the publication in the public portal. please follow below link for the End User Agreement:

www.umlib.nl/taverne-license

Take down policy

If you believe that this document breaches copyright please contact us at:

repository@maastrichtuniversity.nl

providing details and we will investigate your claim.
}

Copyright and moral rights for the publications made accessible in the public portal are retained by the authors and/or other copyright owners and it is a condition of accessing publications that users recognise and abide by the legal requirements associated with these

- Users may download and print one copy of any publication from the public portal for the purpose of private study or research.

- You may not further distribute the material or use it for any profit-making activity or commercial gain

If the publication is distributed under the terms of Article $25 \mathrm{fa}$ of the Dutch Copyright Act, indicated by the "Taverne" license above, 


\title{
Long-term changes in visual outcomes and ocular morphometrics after myopic and toric phakic intraocular lens implantation: Five- and 10-year results
}

\author{
Soraya M.R. Jonker, MD, Tos T.J.M. Berendschot, PhD, Annick E. Ronden, BSc, Isabelle E.Y. Saelens, MD, PhD, \\ Noël J.C. Bauer, MD, PhD, Rudy M.M.A. Nuijts, $M D$, PhD
}

Purpose: To evaluate the long-term refractive and visual, anterior chamber depth, and axial length (AL) changes and complications after rigid iris-fixated phakic intraocular lens ( $\mathrm{plOL}$ ) implantation to treat myopia or astigmatism.

Setting: University Eye Clinic Maastricht, Maastricht UMC+, the Netherlands.

Design: Prospective case series.

Methods: The study evaluated patients who had implantation of an Artisan myopic or toric iris-fixated plOL as of January 1998. Changes were measured annually and reported after 1,5 , and 10 years postoperatively.

Results: The study comprised 460 eyes (250 patients; mean age 41.1 years \pm 10.7 [SD]). Over 10 years, the mean myopization was -0.79 diopters $(D)(P<.001)$, with $52 \%$ of eyes within $\pm 1.0 \mathrm{D}$ of target. The mean increase in the logarithm of the minimum angle of resolution (logMAR) corrected distance visual acuity (CDVA) over 10 years was $0.05(P<.001)$; $95 \%$ of eyes had a CDVA of $20 / 40$ or more and $7 \%$ lost 2 or more lines of CDVA. The mean logMAR uncorrected visual acuity (UDVA) increased by 0.14 over 10 years $(P<.001) ; 96 \%$ had a UDVA $20 / 40$ or better. The AL increased by $1.14 \mathrm{~mm}$ over 10 years $(P=.009)$. Ten percent of plOLs were explanted because of cataract formation after a mean of $97.9 \pm 34.9$ months. A higher preoperative age (hazard ratio [HR], 1.08; $P<.001)$ and longer $\mathrm{AL}(\mathrm{HR}, 1.34 ; P<.001)$ were risk factors for shorter survival because of cataract formation.

Conclusion: Ten years after rigid iris-fixated pIOL implantation, the CDVA and UDVA decreased significantly as a result of significant myopization caused by an increased AL unrelated to the pIOL.

J Cataract Refract Surg 2019; 45:1470-1479 @ 2019 ASCRS and ESCRS
F or more than a decade, phakic intraocular lenses (pIOLs) have been the preferred treatment for high myopia and the correction of myopia in patients unsuited for laser refractive correction because of a thin or ectatic cornea. ${ }^{1,2}$ Previous studies ${ }^{1-5}$ report good visual acuity, predictability, and stability in patients with anterior chamber (angle-supported iris-fixated) or posterior chamber pIOLs. However, to our knowledge only 1 study of irisfixated Artisan pIOLs reported results after a 10-year follow-up ${ }^{4}$ and no previous study assessed the influence of morphologic changes in refractive and visual outcomes.

The purpose of the current prospective study was to report 5-year and 10-year follow-up data on refractive and visual outcomes, morphometric changes, and complications in patients who had implantation of 1 of 2 types of rigid iris-fixated pIOLs.

\section{PATIENTS AND METHODS}

From January 1998 to June 2016, patients had implantation of an Artisan myopic or myopic toric rigid iris-fixated pIOL. The study was performed in adherence with the tenets of the Declaration of Helsinki. The Maastricht University Medical Center Institutional Review Board stated that approval was not required for this study.

Patients were evaluated preoperatively and 1 day, 1 week, and 1 , 3,6 , and 12 months postoperatively. Regular follow-up continued with annual visits. All surgeries were performed by the same surgeon (R.M.M.A.N.) using general or local anesthesia. The 
inclusion criteria, surgical procedure (including peripheral iridectomy), and postoperative medication used in the current study have been described. ${ }^{6,7, \mathrm{~A}}$

\section{Patient Evaluations}

The preoperative examination consisted of subjective and cycloplegic refractions, Snellen uncorrected (UDVA) and corrected (CDVA) distance visual acuity measurements, and slitlamp evaluation, including Goldmann applanation tonometry and fundoscopy. Additional evaluations were corneal topography (Orbscan, Bausch \& Lomb, Inc.), Scheimpflug tomography (Pentacam HR, Oculus Optikgeräte $\mathrm{GmbH}$ ), Scheimpflug cameraPlacido topography (Sirius, Schwind eye-tech-solutions $\mathrm{GmbH}$ \& Co. KG), biometry (A2500, Sonomed Escalon), partial coherence interferometry (IOLMaster, Carl Zeiss Meditec AG), anterior segment optical coherence tomography (AS-OCT) (Visante, Carl Zeiss Meditec AG), and specular microscopy (Noncon Robo SP9000 S/N PK1-1137, Konan Medical, Inc.). All preoperative measurements were performed 1 week after removal of soft contact lenses and 2 weeks after removal of rigid gas-permeable contact lenses.

From 2006 onward, AS-OCT was used to perform preoperative pIOL simulation to measure the anterior chamber depth (ACD), vault between the pIOL and crystalline lens, distance between the anterior pIOL and the endothelium, and clear lens rise as reported previously. ${ }^{8}$

Postoperative annual follow-up visits consisted of subjective refraction, Snellen UDVA and CDVA measurements, slitlamp examination, tonometry, corneal topography, AS-OCT, and specular microscopy.

\section{Outcome Measures}

Refractive and visual outcomes were based on the 2014 guidelines of the Journal of Refractive Surgery, ${ }^{9}$ which describe the manifest refractive spherical equivalent (MRSE), target MRSE versus achieved MRSE, change in MRSE, refractive astigmatism, CDVA, change in CDVA, UDVA, and change in UDVA as the outcome measures for refractive surgery. The target induced astigmatism (TIA) vector, surgically induced astigmatism (SIA) vector, difference vector (between TIA and SIA), correction index (SIA divided by TIA), index of success (difference vector divided by TIA), and mean angle of error were calculated using refractive data in eyes with the myopic toric pIOL. The safety index (postoperative CDVA divided by preoperative CDVA) and efficacy index (postoperative UDVA divided by preoperative CDVA) were computed, and changes in the indices reported.

In addition, the ACD and axial length (AL) and the changes over time were assessed to evaluate possible age-related changes in ocular biometry. Changes in endothelial cell density (ECD) were reported in a previous paper. ${ }^{6}$

\section{Statistical Analysis}

Statistical analysis was performed using SPSS for Windows software (version 23, IBM Corp.). The UDVA and CDVA were converted from Snellen values to logarithm of the minimum angle of resolution $(\log M A R)$ notation for statistical analysis. Descriptive analyses were performed to compute the mean \pm SD of primary outcome measures and preoperative characteristics, and vector analyses according to Alpins were performed to assess refractive astigmatism in eyes with the myopic toric pIOL. ${ }^{10}$

Longitudinal changes were assessed using linear mixed-model analysis with the eye identification number as a grouping variable and time as a covariate. In each model, the best-fit covariance structure was selected using the Bayesian information criterion. To determine long-term changes in the study groups, longitudinal analyses were used to assess short-term changes from preoperatively to 12 months postoperatively and long-term changes from 12 months postoperatively to the end of follow-up. Hotelling trace multivariate analysis of variance analyses were performed to determine whether the vectorial change from 1 to 5 years and 1 to 10 years postoperatively was significantly different from zero.

In a subset of patients, longitudinal analyses and cross-sectional analyses of the effect of age on AL were performed using a linear mixed-model (24 eyes; longitudinal data) and analysis of variance (ANOVA) (181 eyes; preimplantation data), respectively. KaplanMeier and multivariate Cox regression analyses were performed to measure the survival from pIOL implantation to pIOL explantation for cataract formation. All risk factors identified in the univariate Cox regression analyses were added to 1 multivariate Cox regression analysis to correct for possible correlations. A $P$ value less than 0.05 was considered significant.

\section{RESULTS}

The study comprised 460 eyes of 250 patients; the rigid myopic pIOL was implanted in 379 eyes of 207 patients and the rigid myopic toric pIOL in 81 eyes of 51 patients. Table 1 shows the patients' baseline characteristics. The mean follow-up was 90 months \pm 60 (SD).

After extensive parental consultation 4 eyes of 3 contactlens-intolerant patients younger than 18 years had implantation of a myopic pIOL because of anisometropia $(n=2)$ or a high preoperative refraction $(n=2)$. Between 1998 and 2006, no definitive cutoff points were formulated (neither internationally nor by the Netherlands Society for Refractive Surgery) with respect to the preoperative ECD. As a result, a pIOL was implanted in 20 eyes of 16 patients with an ECD lower than 2000 cells $/ \mathrm{mm}^{2}$.

\section{Predictability}

Table 1 shows the MRSE results over time. Figure 1 shows the target MRSE correction versus the achieved MRSE correction at the 3 postoperative timepoints ( 1 year, 5 years, and 10 years). Figure 2 shows the percentage of eyes within \pm 0.50 diopter (D) and $\pm 1.00 \mathrm{D}$ of the target refraction at the 3 postoperative timepoints. Figure 3 shows the change in MRSE over 10 years and the percentage of eyes with a greater than $0.50 \mathrm{D}$ change in the MRSE from 1 year to 5 and 10 years postoperatively. Figure 4 shows the preoperative and postoperative residual refractive astigmatism and percentage of eyes with refractive astigmatism of \pm 0.50 $\mathrm{D}$ or less and $\pm 1.00 \mathrm{D}$ or less from zero. Figures 5 to 7 show single-angle polar plots representing the TIA vector, SIA vector, difference vector, and correction index at 1 year, 5 years, and 10 years, respectively. Figure 8 shows the distribution of the angle of error at the 3 postoperative timepoints. The mean index of success was $0.27 \pm 0.28$, $0.21 \pm 0.19$, and $0.28 \pm 0.22$ at 1 year, 5 years, and 10 years, respectively.

The MRSE decreased by $0.079 \mathrm{D}$ each year; the decrease was statistically significant $(P<.001)$. On vector analysis, the mean change in refractive cylinder in eyes with the toric pIOL was $0.38 \pm 0.62 \mathrm{D}$ at 149 degrees from 1 to 5 years $(P=.023)$ and $0.31 \pm 0.50 \mathrm{D}$ at 112 degrees from 1 to 10 years postoperatively $(P=.29)$.

\section{Safety}

Table 1 shows logMAR CDVA over time. Figure 9 shows the change in Snellen lines of CDVA 5 years and 10 years 
Table 1. Preoperative characteristics and postoperative results.

\begin{tabular}{|c|c|c|c|c|}
\hline \multirow[b]{2}{*}{ Parameter } & \multirow[b]{2}{*}{ Preoperatlve } & \multicolumn{3}{|c|}{ Postoperative } \\
\hline & & 1 Year & 5 Year & 10 Year \\
\hline \multicolumn{5}{|c|}{ Patient characteristics } \\
\hline Mean $\pm S D$ & $41.1 \pm 10.7$ & NR & NR & NR \\
\hline Range & $5.3,68.2$ & NR & NR & $N R$ \\
\hline Men/women (\%) & 37/63 & NR & NR & NR \\
\hline Eyes $(n)$ & 460 & 382 & 250 & 136 \\
\hline \multicolumn{5}{|l|}{ Predictability } \\
\hline \multicolumn{5}{|l|}{ MRSE (D) } \\
\hline Mean $\pm S D$ & $-12.58 \pm 5.15$ & $-0.51 \pm 0.69$ & $-0.81 \pm 0.98$ & $-0.72 \pm 1.48$ \\
\hline Range & $-30.50,0.00$ & $-3.50,1.13$ & $-4.88,1.13$ & $-8.00,3.00$ \\
\hline \multicolumn{5}{|c|}{ Refractive cylinder, D } \\
\hline Mean $\pm S D$ & $-1.64 \pm 1.35$ & $-0.75 \pm 0.65$ & $-0.95 \pm 0.77$ & $-1.25 \pm 0.87$ \\
\hline Range & $-8.50,0.00$ & $-3.50,0.00$ & $-3.50,0.00$ & $-4.50,0.00$ \\
\hline \multicolumn{5}{|l|}{ Safety } \\
\hline \multicolumn{5}{|l|}{ CDVA (logMAR) } \\
\hline Mean $\pm \mathrm{SD}$ & $0.13 \pm 0.18$ & $0.03 \pm 0.16$ & $0.04 \pm 0.15$ & $0.10 \pm 0.23$ \\
\hline Range & $-0.18,1.70$ & $-0.20,1.78$ & $-0.18,1.00$ & $-0.18,2.08$ \\
\hline \multicolumn{5}{|l|}{ Safety index } \\
\hline Mean \pm SD & NA & $1.29 \pm 0.32$ & $1.22 \pm 0.33$ & $1.24 \pm 0.45$ \\
\hline Range & NA & $0.50,2.67$ & $0.50,2.50$ & $0.04,3.00$ \\
\hline \multicolumn{5}{|l|}{ Efficacy } \\
\hline \multicolumn{5}{|l|}{ UDVA (logMAR) } \\
\hline Mean \pm SD & NA & $0.17 \pm 0.23$ & $0.23 \pm 0.27$ & $0.29 \pm 0.29$ \\
\hline Range & NA & $-0.20,1.78$ & $-0.10,1.48$ & $-0.08,1.30$ \\
\hline \multicolumn{5}{|l|}{ Efficacy index } \\
\hline Mean $\pm S D$ & NA & $0.96 \pm 0.32$ & $0.83 \pm 0.32$ & $0.77 \pm 0.35$ \\
\hline Range & NA & $0.10,2.33$ & $0.06,1.60$ & $0.06,2.00$ \\
\hline \multicolumn{5}{|l|}{ IOP (mm Hg) } \\
\hline Mean $\pm S D$ & $14.8 \pm 3.3$ & $15.5 \pm 3.0$ & $15.9 \pm 3.1$ & $16.4 \pm 2.6$ \\
\hline Range & $6.0,30.0$ & $8.0,26.0$ & $10.0,24.0$ & $11.0,25.0$ \\
\hline \multicolumn{5}{|l|}{$\mathrm{ACD}^{\star}(\mathrm{mm})$} \\
\hline Mean $\pm S D$ & $3.13 \pm 0.38$ & $3.12 \pm 0.28$ & $3.11 \pm 0.15$ & $2.86 \pm 0.34$ \\
\hline Range & $2.54,4.51$ & $2.50,3.60$ & $2.90,3.46$ & $2.12,3.40$ \\
\hline
\end{tabular}

$\mathrm{ACD}=$ anterior chamber depth; $\mathrm{AL}=$ axial length; CDVA = corrected distance visual acuity; IOP = intraocular pressure; logMAR = logarithm of the minimum angle of resolution; MRSE = manifest refraction spherical equivalent; NA = not applicable; NR = not reported; UDVA = uncorrected distance visual acuity

${ }^{*}$ Measured from the corneal endothelium

postoperatively as well as the percentage of eyes losing 2 or more Snellen CDVA lines. One year after pIOL implantation, the CDVA was $20 / 40$ or better in 371 eyes $(97 \%)$ and $20 / 20$ or better in 252 eyes (66\%). At 5 years, the CDVA was $20 / 40$ or better in 240 eyes (96\%) and $20 / 20$ or better in 153 eyes $(61 \%)$. The results at 10 years were
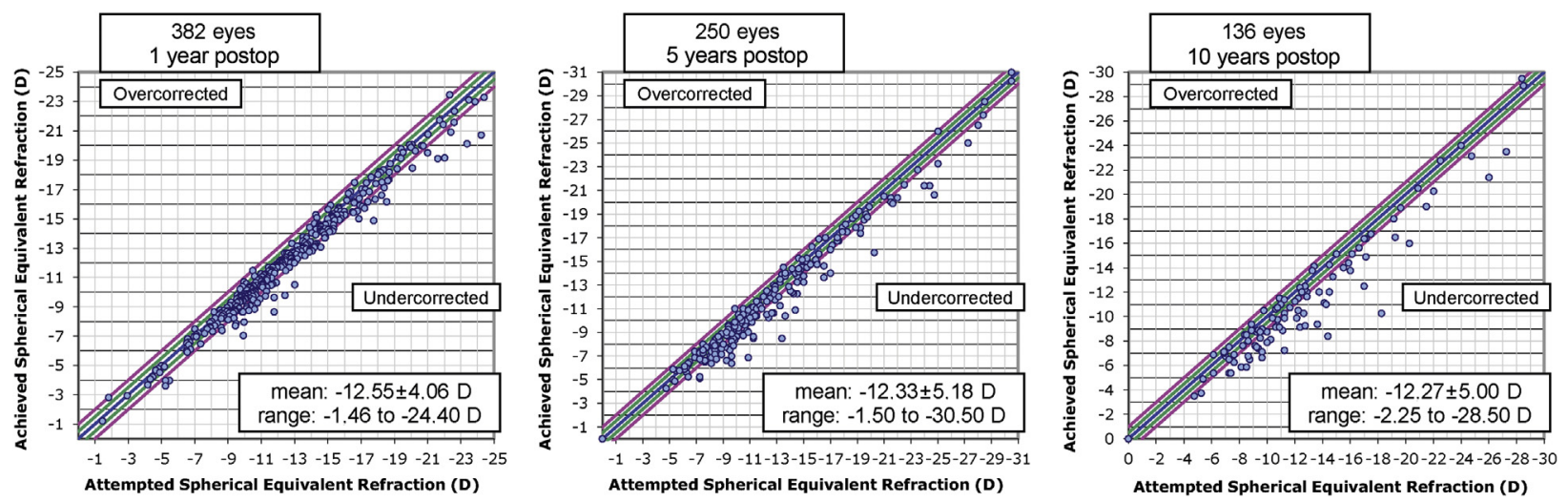

Figure 1. Target versus achieved manifest refraction spherical equivalent correction 1 year, 5 years, and 10 years postoperatively. 

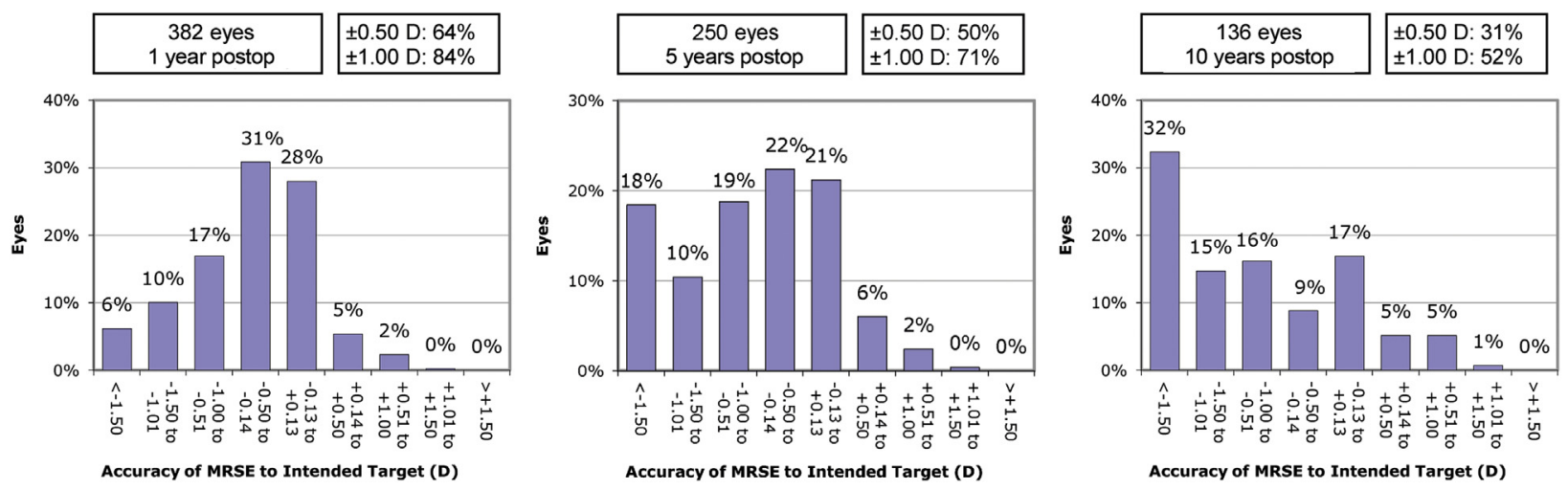

Figure 2. Accuracy of the MRSE 1 year, 5 years, and 10 years postoperatively. MRSE = manifest refractive spherical equivalent.

129 eyes (95\%) and 63 eyes (46\%), respectively. The annual increase in the logMAR CDVA was 0.005 , which was statistically significant $(P<.001)$.

The safety index decreased by 0.010 per year (Table 1 ). The change was statistically significant $(P<.001)$.

\section{Efficacy}

Table 1 shows the mean $\log$ MAR UDVA over time. Figure 10 shows the cumulative Snellen UDVA and Figure 11, the differences in Snellen lines between the UDVA at the 3 postoperative timepoints and the preoperative CDVA. The logMAR UDVA increased by 0.014 each year, which was statistically significant $(P<.001)$.

Table 1 also shows the efficacy index at the 3 postoperative timepoints. Annually, the efficacy index decreased by 0.017 each year, which was statistically significant $(P<.001)$.

\section{Ocular Biometry}

Table 1 shows the mean ACD preoperatively and postoperatively. A longitudinal analysis showed no change in ACD over time $(P=.42)$.

Longitudinal analysis of the AL was performed in a subgroup of 24 eyes that had pIOL implantation as well as combined explantation and cataract surgery at a later date and for which the IOL calculations were performed based on optical biometry AL measurements on both occasions. The mean preoperative AL (measured from the corneal epithelium) was $28.09 \pm 2.24 \mathrm{~mm}$. There was a statistically significant increase in AL of $0.11 \mathrm{~mm}$ per year $(P=.009)$, equaling a total increase of $0.57 \mathrm{~mm}$ and $1.14 \mathrm{~mm}$ after 5 years and 10 years, respectively. A secondary crosssectional analysis (ANOVA) was performed to look at the correlation between age and AL measured with optical biometry devices before pIOL implantation. Analysis of 181 eyes found a similar trend, with the AL increasing significantly by $0.059 \mathrm{~mm}$ each year $(P<.001)$.

\section{Complications and Interventions}

Table 2 shows the postoperative complications and reasons for additional surgery, including pIOL exchange and explantation. No rhegmatogenous retinal detachments (RRDs) occurred in any eye after cataract surgery.

\section{Risk Factors}

After insignificant risk factors were excluded, the Cox regression multivariate analysis identified higher preoperative age (hazard ratio [HR], 1.08; 95\% confidence interval (CI), 1.05-1.12; $P<.001)$ and longer preoperative AL (HR, 1.34; 95\% CI, 1.19-1.50; $P<.001$ ) as significant risk factors for a shorter survival.
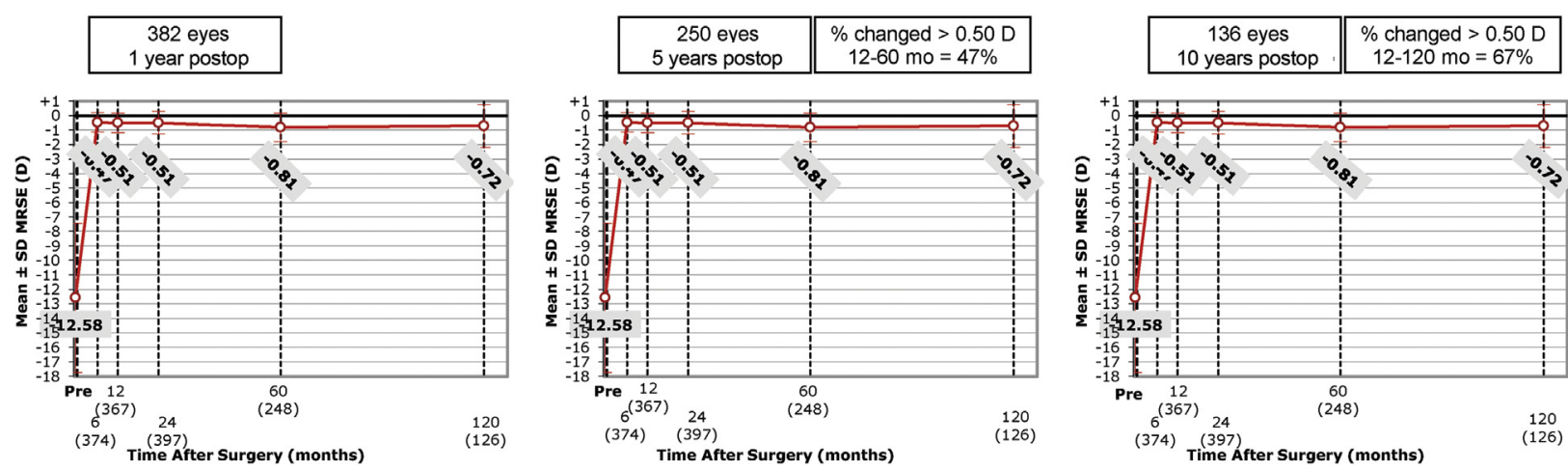

Figure 3. Change in MRSE from preoperatively to 1 year, 5 years, and 10 years postoperatively. MRSE = manifest refractive spherical equivalent. 

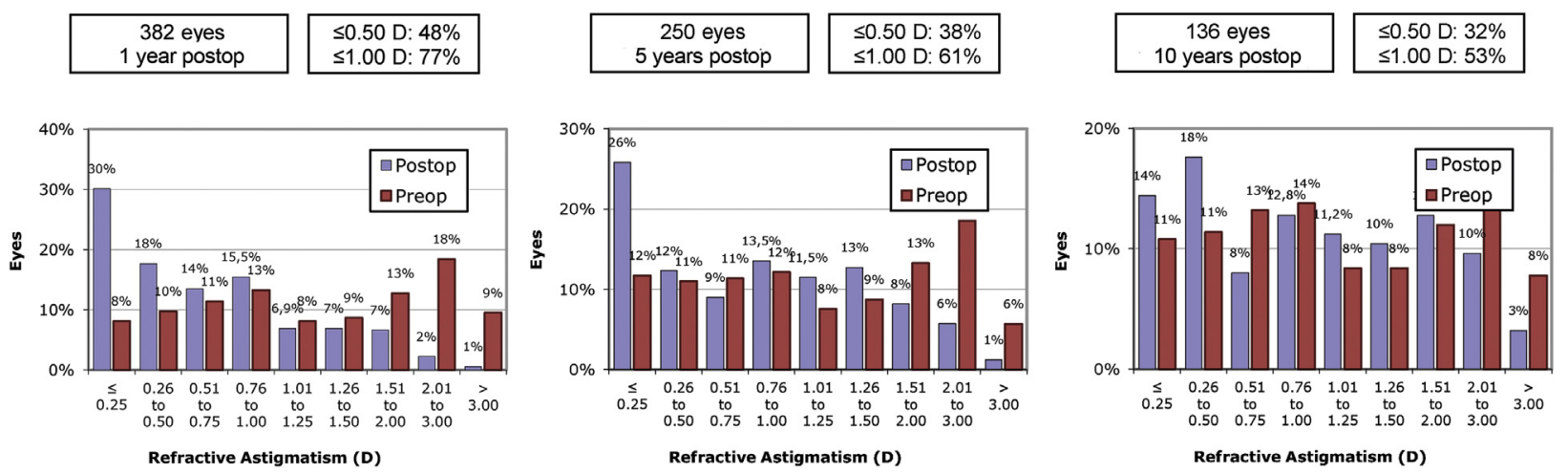

Figure 4. Refractive astigmatism preoperatively and 1 year, 5 years, and 10 years postoperatively.

\section{DISCUSSION}

The current study assessed the refractive and visual outcomes 10 years after iris-fixated pIOL implantation. $^{1-5,11-17}$ The key finding is the age-related AL elongation, which caused significant myopization and affected the long-term predictability and efficacy. We applied linear mixed-model analysis, which is designed to use all available data from each individual patient and is especially useful when testing for significant changes over time (ie, per annum). As such, the current article might serve as a reference for longitudinal change and as a catalyst for further research on AL changes in cases of high myopia.
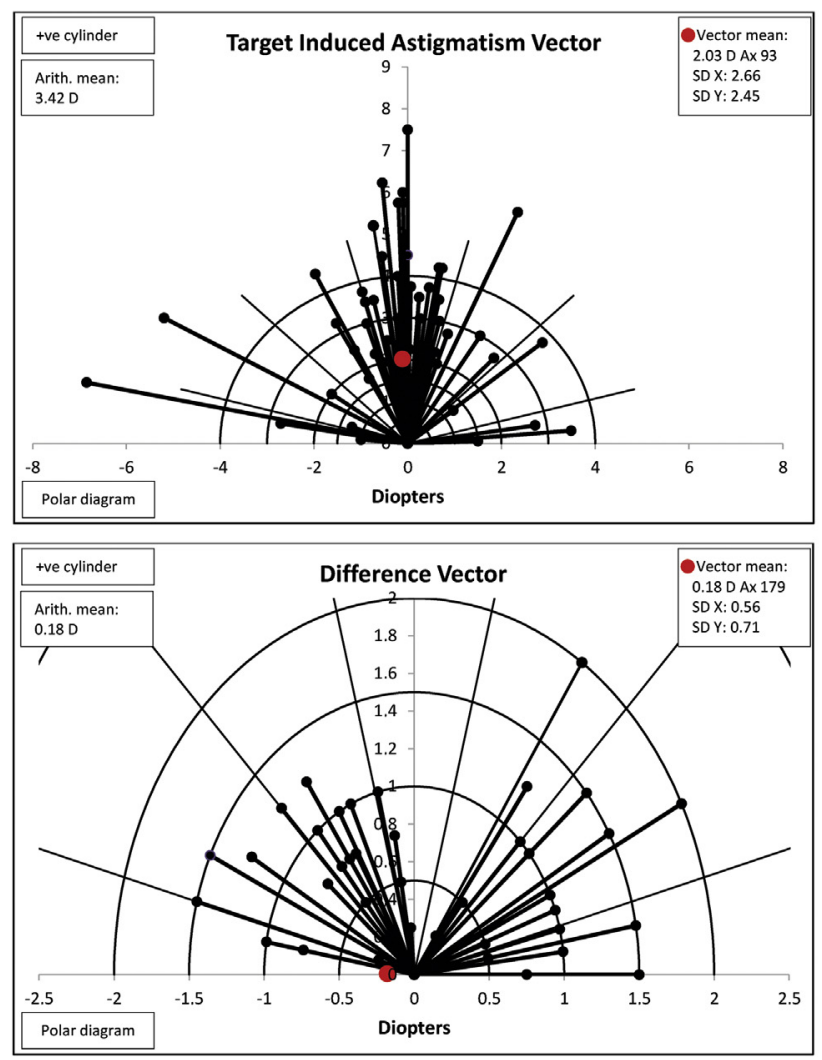

Regarding predictability, even though our 10-year results resemble those in studies with a much shorter followup, ${ }^{4,5,11,12,14-17}$ they are slightly different from the results in the only other study with a 10-years follow-up ${ }^{4}$ (ie, MRSE $-0.70 \mathrm{D}$ and $43.8 \%$ and $68.8 \%$ of eyes within $\pm 0.50 \mathrm{D}$ and $\pm 1.00 \mathrm{D}$ of target refraction, respectively). The lower percentage of eyes within \pm 0.50 and $1.00 \mathrm{D}$ of the target correction in our group is likely related to the fact that 48 eyes in our study developed cataract requiring surgery as opposed to 2 eyes in the previous study. ${ }^{4} \mathrm{We}$ believe that the higher preoperative age and higher myopia in our group (41.1 years and $-12.58 \mathrm{D}$, respectively, in our group versus 38.35 years and $-10.36 \mathrm{D}$, respectively, in the
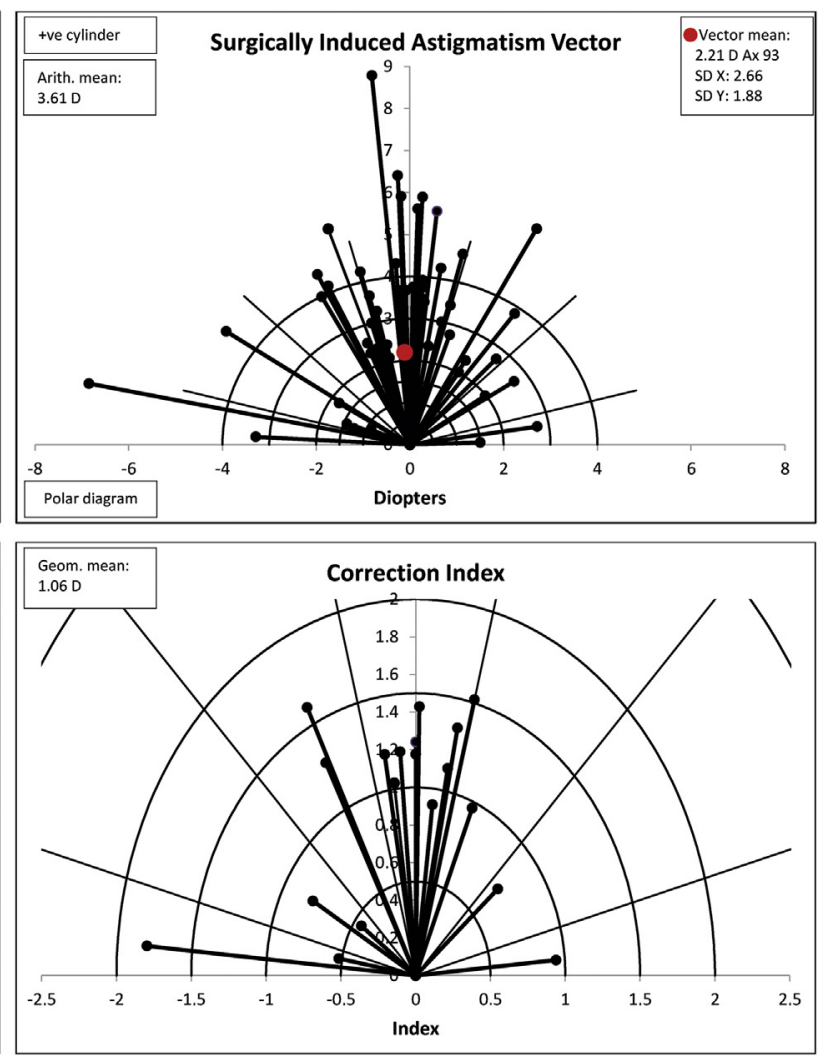

Figure 5. Single-angle polar plots of target induced astigmatism vector, surgically induced astigmatism vector, difference vector, and correction index 1 year after implantation of iris-fixated toric phakic intraocular lens (53 eyes). Arith. = arithemetic; Geom. = geometric. 

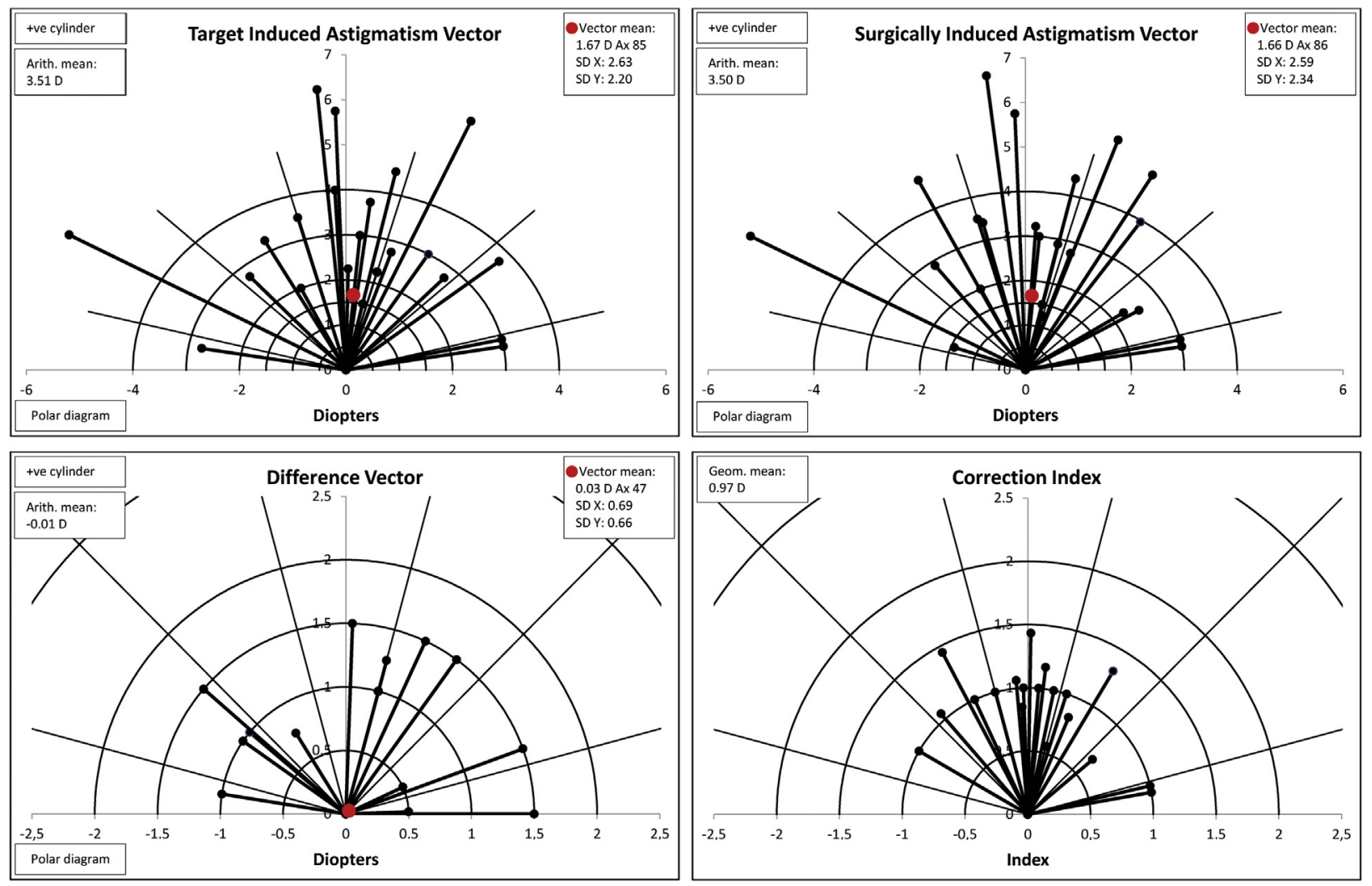

Figure 6. Single-angle polar plots of target induced astigmatism vector, surgically induced astigmatism vector, difference vector, and correction index 5 years after implantation of iris-fixated toric phakic intraocular lens (23 eyes). Arith. = arithemetic; Geom. $=$ geometric.
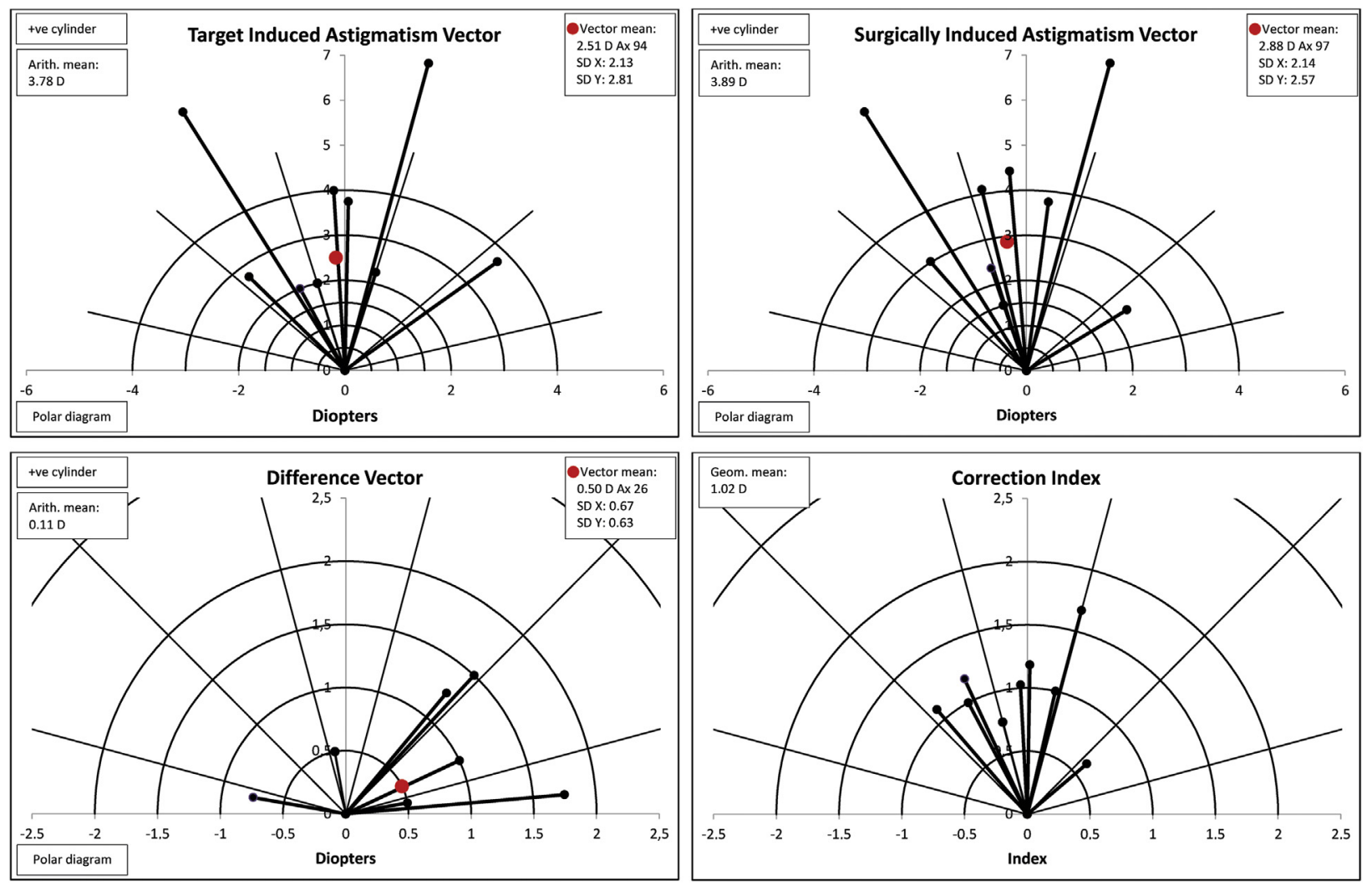

Figure 7. Single-angle polar plots of target induced astigmatism vector, surgically induced astigmatism vector, difference vector, and correction index 10 years after implantation with iris-fixated toric phakic intraocular lens ( 9 eyes). Arith. $=$ arithemetic; Geom. $=$ geometric. 

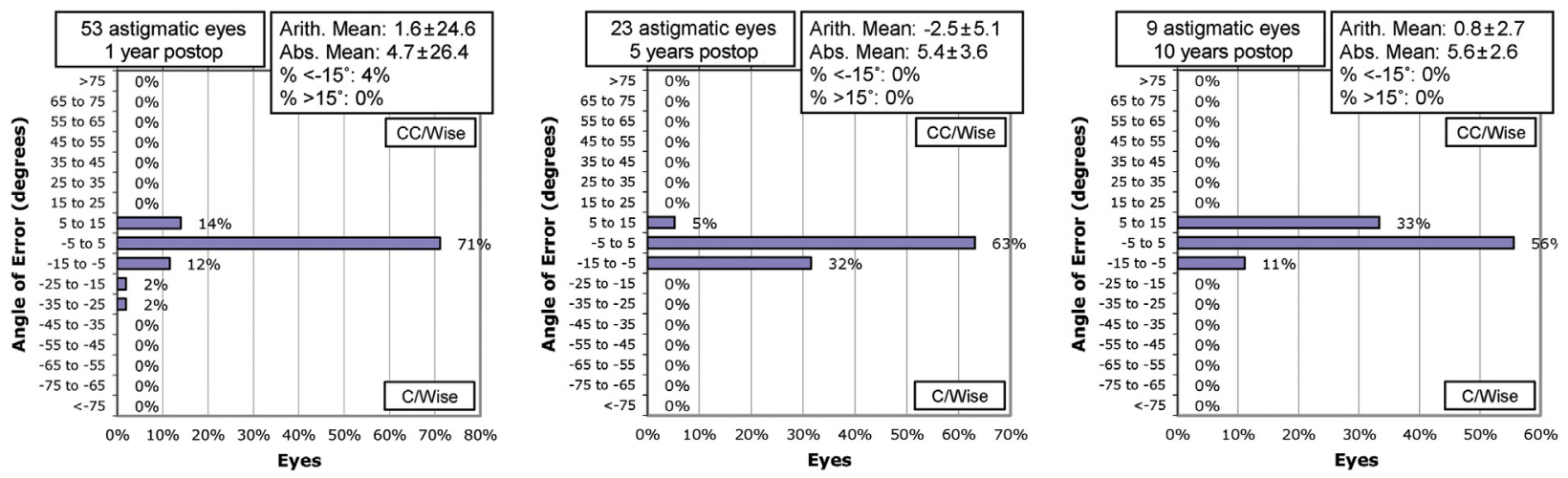

Figure 8. The refractive astigmatism angle of error 1, 5, and 10 years after implantation with iris-fixated toric phakic intraocular lens. Abs. = absolute; Arith. = arithemetic; CC/Wise = counterclockwise; C/Wise = clockwise.

previous study) resulted in a higher risk for developing cataract within 10 years of pIOL implantation. Another explanation is the reported increase in AL over the 10 years of follow-up, which caused axial myopia. Unfortunately, cataract was not graded on a regular basis in the current study; thus, the influence of cataract formation versus $\mathrm{AL}$ elongation on the myopization remains uncertain. Despite the significant change in refractive cylinder from 1 year to 5 years postoperatively, all vector analyses after 5 years showed excellent results. The mean difference vector was $0.03 \mathrm{D}$ at 47 degrees $(0.00 \mathrm{D}$ being the preferred result), and the mean correction index was 0.97 (1.00 being the preferred result). Two previous studies ${ }^{14,16}$ used doubleangle plots to show the refractive cylinder 6 months after toric pIOL implantation; both found a significant reduction in preoperative astigmatism that was equal to our longterm results after 5 years.

Regarding safety, $7 \%$ of eyes lost 2 or more Snellen CDVA lines, a proportion higher than reported values, which vary from $0.9 \%$ to $2.6 \%$ after 3 to 10 years., ${ }^{41-14}$ This might be attributed to the higher incidence of eyes requiring cataract surgery in our study than in other studies $^{4,11-13}$ (7.6\% after 10 years in our group versus $0.0 \%$ to $2.25 \%$ of eyes after 3 to 6 years in the literature) as well as the higher incidence of retinal complications (ie, detachment, hemorrhage, myopic or macular degeneration, macular hole, retinoschisis) $(3.5 \%$ in our group versus in $0.51 \%$ to $3.5 \%$ in the literature [data on file). ${ }^{4,11-13}$ However, the safety index was 1.24 in the myopic pIOL group, higher than the safety index of 1.10 in the only other study with a follow-up of 10 years. ${ }^{4}$

Our efficacy results agree with previously reported findings. The logMAR UDVA, percentage of eyes with a UDVA of 20/40 or better or 20/20 or better, and efficacy index after 10 years were similar to results in previous studies with a follow-up of 3 to 10 years. ${ }^{4,5,11-15,17}$

In our study population, there was not a significant change in ACD measured by ocular biometry. This is in contrast with previous reports using ultrasound ${ }^{18,19}$ or $\mathrm{OCT}^{20}$; these studies found an annual decrease in ACD ranging from $-0.011 \mathrm{~mm}$ to $-0.018 \mathrm{~mm}$. Although we found a myopic shift with advancing time, the mean preoperative age of 40 years makes nuclear sclerosis a less likely explanation for this shift, leading us to focus on a possible increase in AL related to age. Therefore, we evaluated the AL changes in 2 subsets of patients.

The first subset comprised 24 eyes that had combined pIOL explantation and cataract surgery. Longitudinal analysis showed that the AL in these eyes increased $0.11 \mathrm{~mm}$ per year, a significant change. To explore the relationship between age and AL, measurements using optical biometry obtained before pIOL implantation were analyzed in relation to preoperative age. This cross-sectional analysis showed a significant effect of age, with an expected increase
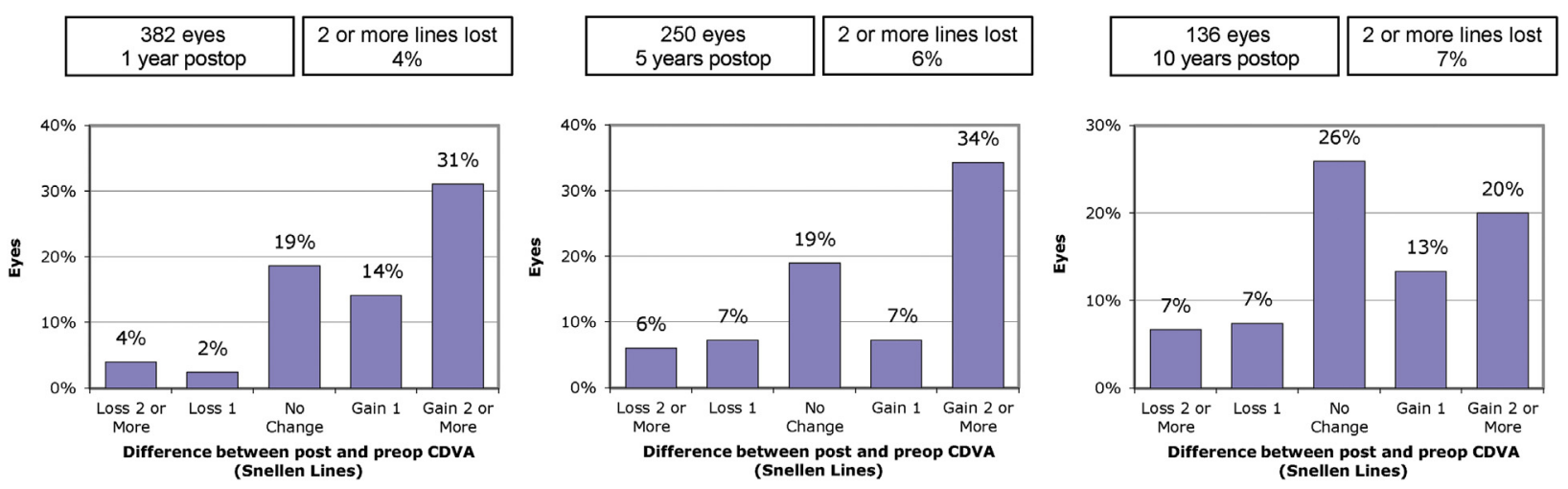

Figure 9. Change in Snellen lines of CDVA 1 year, 5 years, and 10 years postoperatively. CDVA = corrected distance visual acuity. 

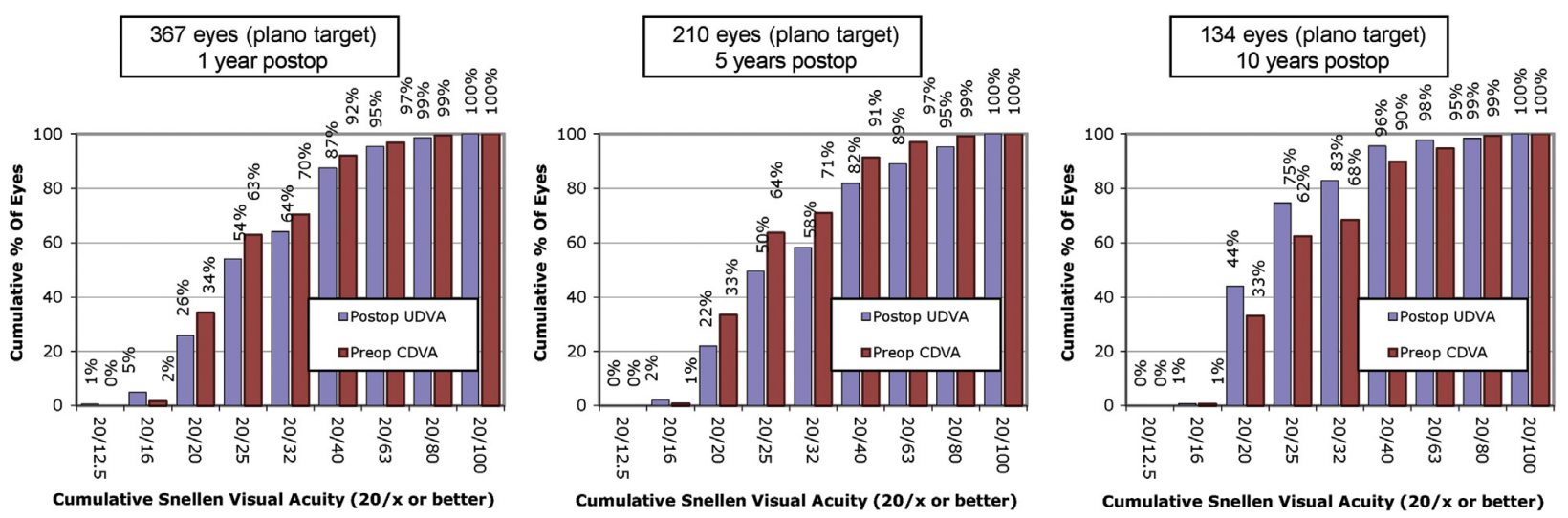

Figure 10. Snellen preoperative CDVA and UDVA 1 year, 5 years, and 10 years postoperatively. CDVA = corrected distance visual acuity; UDVA $=$ uncorrected distance visual acuity.

in $\mathrm{AL}$ of $0.059 \mathrm{~mm}$ per year. The $\mathrm{AL}$ was not reported in the preceding long-term follow-up study, ${ }^{4}$ and previous epidemiology studies assessing the AL change in an adult population $^{9,21,22}$ used ultrasound for longitudinal evaluation or assessed emmetropic eyes only. Because of the small size of our subgroup and because previous publications did not focus on AL changes in eyes with high myopia, our results, rather than a standard age-related effect, should be regarded as a possible trend in AL changes in an adult population of patients with high myopia.

Retinal detachment (RD) occurred in $1.09 \%$ of eyes in our study; other studies report an incidence of $0.25 \%$ to $0.39 \%$ after 3 to 5 years of follow-up., ${ }^{5,12}$ Previous studies $^{1,23-25}$ identified high myopia, defined as either $-3.0 \mathrm{D}$ or $-6.0 \mathrm{D}$, as a significant risk factor for RRD. As a result, the high preoperative MRSE of $-12.58 \mathrm{D}$ and mean preoperative AL of $28.09 \mathrm{~mm}$ in our study likely contributed to the higher total percentage of $\mathrm{RD}$ and myopic macular degeneration. In addition, other studies $^{24,25}$ found the risk for RD to be higher in pseudophakic eyes as a result of volumetric changes in the vitreous and an inflammatory reaction after phacoemulsification, leading to RRD in $0.55 \%$ of eyes and $1.17 \%$ of eyes after a mean follow-up of 4.3 years and 3.3 years, respectively. Combined pIOL explantation and cataract surgery did not result in RRD in any patient in this cohort. Myopic macular degeneration in highly myopic eyes with an $\mathrm{AL}$ similar to that in our cohort (mean $29.8 \pm 1.7 \mathrm{~mm}$ ) and a mean follow-up of 13 years resulted in choroidal neovascularization in $10.2 \%$ of eyes in a 2003 study. ${ }^{26}$ It might be advisable to alert patients with myopic macular degeneration who request pIOL implantation of this risk for visual complications and to keep in mind that high myopia in itself can cause severe visual complications regardless of intraocular surgery.

Additional laser refractive touch-up surgery (eg, photorefractive keratectomy) was required in $3.26 \%$ of eyes in the current study versus rates of $5.95 \%$ to $14.85 \%$ reported in the literature. ${ }^{5,27}$ Güell et al. ${ }^{28}$ hypothesized that laser in situ keratomileusis in an eye with an anterior chamber pIOL might induce contact between the corneal endothelium and the PIOL when the microkeratome is used, which could be a good reason to perform photorefractive keratectomy instead in eyes with an anterior chamber pIOL.

Cataract formation rates were higher in our group than in previous studies, which reported cataract in $0.25 \%$ of eyes after 3 years and in $3.04 \%$ of eyes after 8 years. ${ }^{13,29}$ We do not believe that cataract formation was caused by the pIOL but rather that the higher mean patient age and longer mean AL might have been causative factors. ${ }^{1,30,31}$ This hypothesis was validated by additional Kaplan-Meier and Cox regression analyses that assessed survival until pIOL
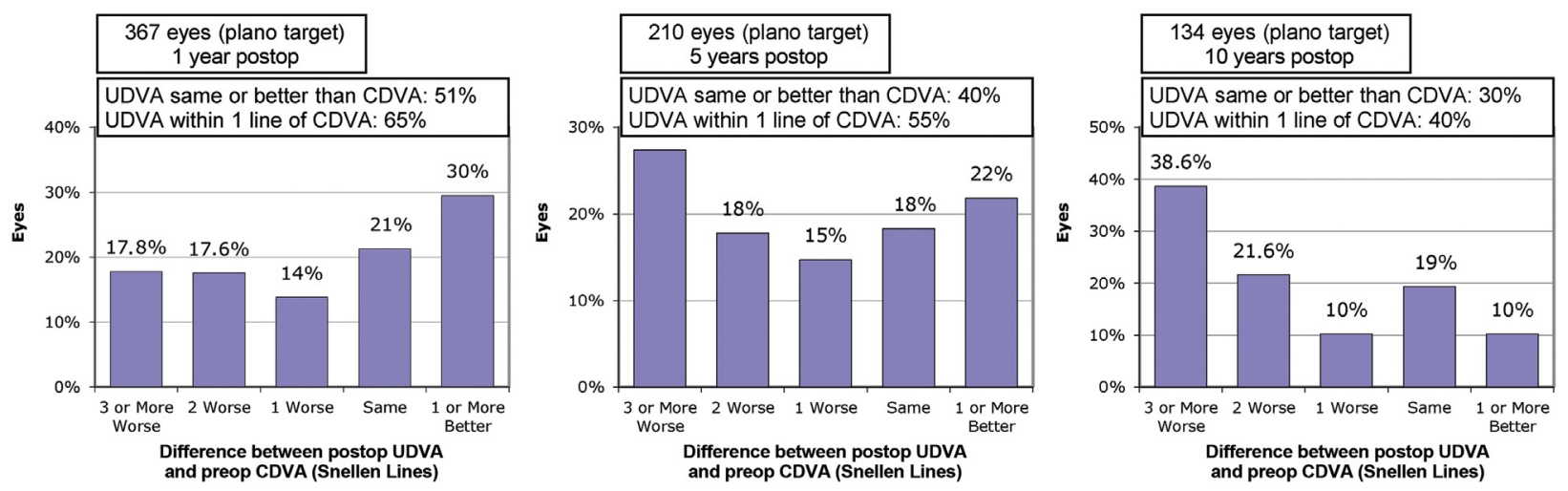

Figure 11. Difference in Snellen lines between postoperative UDVA and preoperative CDVA 1 year, 5 years, and 10 years postoperatively. CDVA $=$ corrected distance visual acuity; UDVA = uncorrected distance. 
Table 2. Sight-threatening events, secondary surgical interventions, and plOL exchanges and explantations in entire cohort (460 eyes).

\begin{tabular}{|c|c|c|c|c|}
\hline \multirow[b]{2}{*}{ Event/Surgery } & \multirow[b]{2}{*}{ Eyes/Patients (n) } & \multirow[b]{2}{*}{ Ratio (\%) } & \multicolumn{2}{|c|}{ Time (Mo) } \\
\hline & & & Mean \pm SD & Range \\
\hline \multicolumn{5}{|l|}{ Retinal event } \\
\hline Retinal detachment & $5 / 5$ & 1.09 & $37.8 \pm 30.6$ & $0.9,80.1$ \\
\hline Myopic macular degeneration & $8 / 6$ & 1.74 & $102.2 \pm 45.5$ & $1.0,144.8$ \\
\hline Retinoschisis & $2 / 2$ & 0.43 & 36.0 and 108.0 & - \\
\hline Macular hole & $1 / 1$ & 0.22 & 3.0 & - \\
\hline Central serous chorioretinopathy & $1 / 1$ & 0.22 & 84.0 & - \\
\hline \multicolumn{5}{|l|}{ Secondary surgical intervention } \\
\hline \multicolumn{5}{|l|}{ Laser refractive correction } \\
\hline PRK & $15 / 9$ & 3.26 & $37.5 \pm 21.4$ & $3.2,63.1$ \\
\hline \multicolumn{5}{|l|}{ pIOL refixation } \\
\hline Traumatic subluxation & $2 / 2$ & 0.43 & 9.0 and 29.4 & - \\
\hline Insufficient enclavation & $1 / 1$ & 0.22 & 34.5 & - \\
\hline Glare & $1 / 1$ & 0.22 & 4.6 & - \\
\hline Misalignment & $1 / 1$ & 0.22 & 4.4 & - \\
\hline \multicolumn{5}{|l|}{ plOL exchange } \\
\hline Undercorrected & $2 / 2$ & 0.43 & 1.4 and 1.4 & - \\
\hline Overcorrected & $1 / 1$ & 0.22 & 3.9 & - \\
\hline Refractive change & $1 / 1$ & 0.22 & 84.2 & - \\
\hline Additional toric correction & $1 / 1$ & 0.22 & 15.8 & - \\
\hline \multicolumn{5}{|l|}{ plOL explantation } \\
\hline Cataract & $46 / 32$ & 10.00 & $97.9 \pm 34.9$ & $13.8,163.7$ \\
\hline EC loss* & $22 / 15$ & 4.78 & $126.9 \pm 41.7$ & $44.4,182.9$ \\
\hline Cataract and EC loss & $5 / 4$ & 1.09 & $153.4 \pm 22.6$ & 120.0, 179.7 \\
\hline High IOP & $4 / 2$ & 0.87 & $53.2 \pm 26.5$ & $25.7,80.3$ \\
\hline Anisometropia & $1 / 1$ & 0.22 & 15.6 & - \\
\hline Decentration & $1 / 1$ & 0.22 & 1.4 & - \\
\hline Recurrent retinal detachment ${ }^{\dagger}$ & $1 / 1$ & 0.22 & 82.8 & - \\
\hline
\end{tabular}

$\mathrm{EC}=$ endothelial cell; IOP $=$ intraocular pressure; $\mathrm{PRK}=$ photorefractive keratectomy

${ }^{*}$ Corneal edema requiring Descemet stripping automated endothelial keratoplasty in 1 eye of 1 patient and corneal edema requiring penetrating keratoplasty in 1 eye of 1 patient

${ }^{\dagger}$ Recurrent retinal detachment requiring retinal surgery in 1 eye of 1 patient

explantation performed because of cataract formation in the current study. A recent paper by our group ${ }^{32}$ provided an in-depth evaluation of survival until pIOL explantation in all patients with iris-fixated pIOLs at our clinic. It estimated that $25 \%$ and $50 \%$ of iris-fixated pIOLs would be explanted after 134.3 months and 182.9 months, respectively. ${ }^{32}$

In conclusion, age-related AL elongation, possibly together with cataract formation, resulted in significant myopization and caused a decrease in CDVA and UDVA. To our knowledge, no previous study has reported axial elongation in highly myopic eyes, mainly because these studies were cross-sectional, focused on emmetropic eyes, and used error-prone techniques (ie, ultrasound) to measure AL. ${ }^{19,21,22}$ Based on our results, we believe that the myopic shift and higher rates of cataract formation should be attributed to a higher preoperative age and longer AL rather than to the intraocular presence of the pIOL. Myopization induced by AL elongation might suggest implantation of pIOLs with a slight hyperopic target to anticipate this refractive change. However, inducing hyperopia in a formerly highly myopic patient is likely to result in unhappy patients and is not advised. Additional research on longitudinal changes in refractive error and $\mathrm{AL}$ in a highly myopic population is indicated to map physiologic changes against our results after pIOL implantation. Refractive surgeons should counsel patients on the longterm changes in visual outcomes after pIOL implantation in cases of high myopia.

\section{WHAT WAS KNOWN}

- Implantation of iris-fixated phakic intraocular lenses (pIOLs) provides excellent visual and refractive results in highly myopic patients.

- Over time, increased crystalline lens swelling decreases the anterior chamber depth, causing the $\mathrm{pIOL}$ to rise.

\section{WHAT THIS PAPER ADDS}

- Significant myopization might occur in highly myopic adults as a result of axial elongation

- Combined iris-fixated plOLs explantation and cataract surgery did not seem to result in increased rates of retinal detachments in a group of highly myopic patients. 


\section{REFERENCES}

1. Kohnen T, Kook D, Morral M, Güell JL. Phakic intraocular lenses. Part 2: results and complications. J Cataract Refract Surg 2010; 36:2168-2194

2. Huang D, Schallhorn SC, Sugar A, Farjo AA, Majmudar PA, Trattler WB, Tanzer DJ. Phakic intraocular lens implantation for the correction of myopia; a report by the American Academy of Ophthalmology (Ophthalmic Technology Assessment). Ophthalmology 2009; 116:2244-2258

3. Kohnen T, Maxwell WA, Holland S. Correction of moderate to high myopia with a foldable, angle-supported phakic intraocular lens; results from a 5-year open-label trial. Ophthalmology 2016; 123:1027-1035

4. Tahzib NG, Nuijts RM, Wu WY, Budo CJ. Long-term study of Artisan phakic intraocular lens implantation for the correction of moderate to high myopia; ten-year follow-up results. Ophthalmology 2007; 114:1133-1142

5. Güell JL, Morral M, Gris O, Gaytan J, Sisquella M, Manero F. Five-year follow-up of 399 phakic Artisan-Verisyse implantation for myopia, hyperopia, and/or astigmatism. Ophthalmology 2008; 115:1002-1012

6. Jonker SMR, Berendschot TTJM, Ronden AE, Saelens IEY, Bauer NJC, Nuijts RMMA. Long-term endothelial cell loss in patients with artisan myopia and Artisan toric phakic intraocular lenses; 5- and 10-year results. Ophthalmology 2018; 125:486-494

7. Doors M, Cals DWJK, Berendschot TTJM, de Brabander J, Hendrikse F, Webers CAB, Nuijts RMMA. Influence of anterior chamber morphometrics on endothelial cell changes after phakic intraocular lens implantation. J Cataract Refract Surg 2008; 34:2110-2118

8. Baikoff G. Anterior segment OCT and phakic intraocular lenses: a perspective. J Cataract Refract Surg 2006; 32:1827-1835

9. Reinstein DZ, Archer TJ, Randleman JB. JRS standard for reporting astigmatism outcomes of refractive surgery [editorial]. J Refract Surg 2014; 30:654-659; erratum 2015; 31:129

10. Alpins NA, Goggin M. Practical astigmatism analysis for refractive outcomes in cataract and refractive surgery. Surv Ophthalmol 2004; 49:109-122

11. Titiyal JS, Sharma N, Mannan R, Pruthi A, Vajpayee RB. Iris-fixated intraocular lens implantation to correct moderate to high myopia in Asian-Indian eyes: five-year results. J Cataract Refract Surg 2012; 38:1446-1452

12. Budo C, Hessloehl JC, Izak M, Luyten GPM, Menezo JL, Sener BA, Tassignon MJ, Termote H, Worst JGF. Multicenter study of the Artisan phakic intraocular lens. J Cataract Refract Surg 2000; 26:1163-1171

13. Stulting RD, John ME, Maloney RK, Assil KK, Arrowsmith PN, Thompson VM, for the U.S. Verisyse Study Group. Three-year results of Artisan/Verisyse phakic intraocular lens implantation; results of the United States Food and Drug Administration Clinical Trial. Ophthalmology 2008; 115:464-472.e1

14. Bartels MC, Saxena R, van den Berg TJPT, van Rij G, Mulder PGH, Luyten GPM. The influence of incision-induced astigmatism and axial lens position on the correction of myopic astigmatism with the Artisan toric phakic intraocular lens. Ophthalmology 2006; 113:1110-1117

15. Tehrani M, Dick HB. Iris-fixated toric phakic intraocular lens: three-year follow-up. J Cataract Refract Surg 2006; 32:1301-1306

16. Dick HB, Alió J, Bianchetti M, Budo C, Christiaans BJ, El-Danasoury MA, Güell JL, Krumeich J, Landesz M, Loureiro F, Luyten GPM, Marinho A, Rahhal MS, Schwenn O, Spirig R, Thomann U, Venter J. Toric phakic intraocular lens; European multicenter study. Ophthalmology 2003; 110:150-162

17. Güell JL, Vázquez M, Malecaze F, Manero F, Gris O, Velasco F, Hulin H, Pujol J. Artisan toric phakic intraocular lens for the correction of high astigmatism. Am J Ophthalmol 2003; 136:442-447

18. Richdale K, Bullimore MA, Sinnott LT, Zadnik K. The effect of age, accommodation, and refractive error on the adult human eye. Optom Vis Sci 2016; 93:3-11

19. Atchison DA, Markwell EL, Kasthurirangan S, Pope JM, Smith G, Swann PG. Age-related changes in optical and biometric characteristics of emmetropic eyes. J Vis 2008; 8 (4):29

20. Baikoff G, Lutun E, Ferraz C, Wei J. Static and dynamic analysis of the anterior segment with optical coherence tomography. J Cataract Refract Surg 2004; 30:1843-1850

21. McBrien NA, Adams DW. A longitudinal investigation of adult-onset and adult-progression of myopia in an occupational group; refractive and biometric findings. Invest Ophthalmol Vis Sci 1997; 38:321-333
22. Gudmundsdottir E, Arnarsson A, Jonasson F. Five-year refractive changes in an adult population; Reykjavik Eye Study. Ophthalmology 2005; 112:672-677

23. Mitry D, Charteris DG, Fleck BW, Campbell H, Singh J. The epidemiology of rhegmatogenous retinal detachment: geographical variation and clinical associations. Br J Ophthalmol 2010; 94:678-684

24. Bhagwandien ACE, Cheng YYY, Wolfs RCW, van Meurs JC, Luyten GPM Relationship between retinal detachment and biometry in 4262 cataractous eyes. Ophthalmology 2006; 113:643-649

25. Russell M, Gaskin B, Russell D, Polkinghorne PJ. Pseudophakic retinal detachment after phacoemulsification cataract surgery; ten-year retrospective review. J Cataract Refract Surg 2006; 32:442-445

26. Ohno-Matsui K, Yoshida T, Futagami S, Yasuzumi K, Shimada N, Kojima A Tokoro T, Mochizuki M. Patchy atrophy and lacquer cracks predispose to the development of choroidal neovascularisation in pathological myopia. $\mathrm{Br}$ J Ophthalmol 2003; 87:570-573

27. Meltendorf $\mathrm{C}$, Cichocki M, Kohnen $\mathrm{T}$. Laser in situ keratomileusis following the implantation of iris-fixated phakic intraocular lenses. Ophthalmologica 2008; 222:69-73

28. Güell JL, Vázquez M, Gris O. Adjustable refractive surgery: 6-mm Artisan lens plus laser in situ keratomileusis for the correction of high myopia. Ophthalmology 2001; 108:945-952

29. Menezo JL, Peris-Martínez C, Cisneros-Lanuza AL, Martínez-Costa R. Rate of cataract formation in 343 highly myopic eyes after implantation of three types of phakic intraocular lenses. J Refract Surg 2004; 20:317-324

30. Prokofyeva E, Wegener A, Zrenner E. Cataract prevalence and prevention in Europe: a literature review. Acta Ophthalmol 2013; 91:395-405

31. Pan C-W, Cheng C-Y, Saw S-M, Wang JJ, Wong TY. Myopia and agerelated cataract: a systematic review and meta-analysis. Am J Ophthalmol 2013; 156:1021-1033

32. Jonker SMR, Van Averbeke AAC, Berendschot TTJM, Saelens IEY, Nuijts RMMA. Risk factors for explantation of iris-fixated phakic intraocular lenses. J Cataract Refract Surg 2019 In press

\section{OTHER CITED MATERIAL}

A. Consensus Refractiechirurgie Februari 2006 Herzien: juli 2009 Auteurs ver sie februari 2006 V. Aalders-Deenstra, J.Beerthuizen, P.J.D. Bolmers, J.M den Boon, R. Braakman, P.S.J.R. Crobach, C.A. Eggink, A.J.M. Geerards, A.D. Kraaijenga, M. Luger, G.P.M. Luyten, M.Odenthal, A. Rijneveld, van Rooij, A.P.J. Rouwen, C.J.G. van Tilburg, P. Tutein Nolthenius, N.H.Trap C. Verdoorn. Aanvullingen herziene versie juli 2009 door: M. Bartels, J. Beerthuizen, M. Copper, M. Landesz, R. Lapid, H. Van Nouhuijs, R.Nuyts, O.Wolter, J. Van Rooy, N. Trap. Available at: http://www.ooglaseradvies .org/wp-content/uploads/2011/03/consensus-refractiechirurgie-2009 .pdf. Accessed July 15, 2019

Disclosures: Dr. Bauer receives grants and personal fees from Alcon Laboratories, Inc., personal fees from Bausch + Lomb, Inc., and grants from Ophtec BV outside the submitted work. Dr. Nuijts receives grants from Abbott Medical Optics, Inc., Bausch \& Lomb, Inc., Carl Zeiss Meditec AG, HumanOptics AG, Oculentis GmbH, Ophtec BV, grants and personal fees from Alcon Laboratories, Inc., and personal fees from ASICO LLC and Théa Pharma GmbH outside the submitted work. None of the other authors has a financial or proprietary interest in any material or method mentioned.

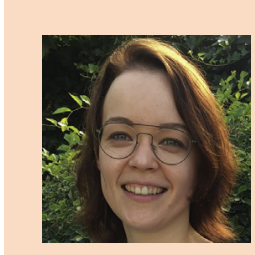

First author: Soraya M.R. Jonker, MD

University Eye Clinic Maastricht, Maastricht University Medical Center, the Netherlands 